\title{
Thidiazuron and Explant Type Effects on High-frequency In Vitro Mass Propagation of Cherry Tomato
}

\author{
Genesia Farouk Omar \\ Department of Horticulture, Faculty of Agriculture, Suez Canal University, Ismailia-41522, Egypt
}

Received: 10/3/2019

\begin{abstract}
Cherry Tomato is one of the most important vegetable crops cultivated for export in Egypt. In vitro culture response was assessed in tomato (Solanum lycopersicum L. var. cerasiforme) cv. (Summer Cherry) for optimum callus induction and plantlet regeneration. Callus induction was achieved within eight to 12 days directly on the cut surfaces of hypocotyl, cotyledon and leaf disc explants cultured on Murashige and Skoog (MS) basal medium supplemented with various concentrations of Thidiazuron (TDZ)] and benzyl adenine (BA) alone, but not in hormone free-medium. The highest callusing index (3.9 and 3.7) was obtained on hypocotyl explants cultured on MS medium supplemented with TDZ(1.0 and $2.0 \mathrm{mgl}^{-1}$ ) followed by an index of 3.5 obtained from the same explant by using $0.5 \mathrm{mgl}^{-1}$ BA. However, for the leaf disc explants, the highest callusing index (3.1) was obtained on MS medium supplemented with BAat $2.0 \mathrm{mgl}^{-1}$. After 8 weeks of culture, organogenesis was observed only on the explants cultured on medium containing different concentrations of TDZ and BA. The best shoot formation $(93 \%)$ was obtained from leaf disc explant callus induced on MS medium containing TDZ. The highest number (13.4) of shootsexplant ${ }^{-1}$ was found when cotyledon explant callus was sub cultured on MS medium supplemented with $2.0 \mathrm{mgl}^{-1} \mathrm{TDZ}$. Half strength of MS was found to be the best rooting medium, however, addition of IAA at $1.0 \mathrm{mgl}^{-1}$ and IBA at $2.0 \mathrm{mgl}^{-1}$ were found necessity to induce highest number of roots $(22.5)$ and longer roots $(11.0 \mathrm{~cm})$, respectively. Acclimation of in vitro rooted plant is important for testing the post culture behavior of tissue culture regenerated plants. Cherry tomato derived from different explant sources under different concentration of TDZ and BA were not significantly different in their vegetative characters to those obtained from seed. However number of (raceme plant ${ }^{-1}$, flower raceme ${ }^{-1}$, fruit raceme ${ }^{-1}$, fruit plant ${ }^{1}$ ) which produced by seed-derived plants was significantly less than those derived from in vitro propagated plants. This protocol would be valuable to create somaclonal variation and develop transgenic approaches for varietal improvement of cherry tomato.
\end{abstract}

Keywords: Solanum lycopersicum L. var. cerasiforme, callus induction, organogenesis, TDZ, acclimatization

\section{INTRODUCTION}

Cherry tomato (Solanum lycopersicum L. var. cerasiforme) previously called Lycopersicon esculentum Mill. (The Natural History Museum, 2011) is a cultivated variety of tomato. It is generally considered to be similar but not identical to the wild relatives of the domestic tomato. There are around 7500 tomato varieties grown for various purposes around the world (Wikipedia, 2011). Various tissue culture studies had been carried out on different varieties of tomato (Afroz et al., 2010; Chaudhry et al., 2010; Gubis et al., 2004; Jabeen et al., 2005), but still there are no results released on cherry tomato.

Cultivation of this valuable crop is expanding day by day because of its high economic values in the vegetables market. It is a rich source of minerals (iron), vitamins (A \& C), organic acid, essential amino acids, and dietary fibers also can be used in preserved food stuffs like ketch-up, sauce, chutney, soup, paste etc. (Block et al., 1992; Gerster, 1997; Rao and Agarwal, 2000). Tomato cultivated area and productivity in Egypt is estimated by 180,000 hectares and $35.5 \mathrm{t} / \mathrm{ha}$, respectively (FAO 2016). The current tomato productivity in Egypt is about half of USA productivity $(66.57 \mathrm{t} / \mathrm{ha})$. Cultivation of tomato suffers from serious losses because of infestation by insects and pests and the diseases they transmit. For that reason, there is an important for biotechnological interventions to rise the productivity of this crop. Culture of plant cell, tissues in vitro is an integral part plant biotechnology, which has been exploited for in vitro regeneration and genetic upgrading of this crop, as the first step towards genetic transformation of plants. Exclusive of a reliable, reproducible and well-organized system to regenerate genetically identical plants from a small mass of transformed cells, it is not possible to generate a complete genetically modified plant. There are several reports on adventitious in vitro cultivation in tomato from various explants (Moghaleb et al., 1999; Brichkova et al., 2002; Raziuddin et al., 2004; Mohamed et al., 2010; Liza et al., 2013). Nevertheless, improvement and standardization of in vitro regeneration and shoot multiplication protocols is still imperative due to its diverse morphogenic potential of different explants and genotypes (Tomsone et al., 2004). On the other hand, there are some limitations of in vitro technique because of the occurrence of spontaneous genetic or epigenetic changes leading to cytological irregularities, phenotypic mutations, sequence changes (Kaeppler et al., 2000), and DNA methylation in in vitro regenerated plants. These differences may affect the quality and quantity of plants as well as genetic transformation through various approaches. The presence of TDZ, either alone or in combination with other growth regulators, is important for shoot organogenesis in a wide variety of plant species (Jiang et al., 2005).

This study was aimed to formulate an efficient and reproducible regeneration system of cherry tomato by optimization of various factors viz., type of explants 
(hypocotyl, cotyledon and leaf disc), medium type (solide and half strength) and plant growth regulators (TDZ) and (BA) alone in different concentrations for in vitro multiplication and plant regeneration. Furthermore, the genetic stability of cherry tomato plants derived from in vitro developed plants was also assessed and compared with the same cherry tomato cultivar plants obtained from mature commercial seed. In the end of this experiment results presented if it is possible of using this protocole for secure micropropagation of valuable genotypes or breeding lines and hybrids in short time which might accelerate the breeding efforts of tomato plants.

\section{MATERIALS AND METHODS}

\section{Experimental materials and surface sterilization}

The current study was conducted at The Plant Tissue Culture Lab, Department of Horticulture, Suez Canal University, Ismailia, Egypt during the years 2017 and 2018, each experiment repeated twice the time. Mature seeds of cherry tomato (Solanum lycopersicum L. var. cerasiforme) (Summer Cherry) were obtained from the United States, USDA ARS
Plant Genetic Resources Unit. Seeds were thoroughly washed under tap water in the laboratory for $30 \mathrm{~min}$, followed by several washes with sterile ultrapure water. The seeds were surface sterilized by $5 \%$ Clorox (Sodium hypochlorite) for $10 \mathrm{~min}$, followed by three times rinses with autoclaved distilled water $(15 \mathrm{~min}$.) under laminar air flow hood (Franklin and Dixon, 1994).

\section{Seed Germination: Culture Media and Conditions}

The sterilized seeds were aseptically and cultured in $250 \mathrm{~mL}$ glass flask, containing $30 \mathrm{~mL}$ of MS (Murashige and Skoog 1962) medium without plant growth regulator (PGR), all media contained 3\% sucrose, the medium $\mathrm{pH}$ was adjusted to 5.8 before adding $7 \mathrm{gl}^{-1}$ plant agar prior to autoclaving at $110 \mathrm{kPa}$ for $20 \mathrm{~min}$ at $121^{\circ} \mathrm{C}$. Cultured explants were incubated in a controlled environment at $25 \pm 2^{\circ} \mathrm{C}$ and $50 \pm 10 \%$ relative humidity $(\mathrm{RH})$. The cultured seeds were incubated in darkness for $48 \mathrm{~h}$ and thereafter maintained under $50 \mu \mathrm{molm}^{-2} \mathrm{~s}^{-1}$ light provided by cool white fluorescent lamp for a photoperiod of $16 \mathrm{~h}$. It was observed that germination was possible after 12 - 14 days of culture (Fig 1.).



Fig (1): In vitro germinated seedling of cherry tomato (Summer Cherry) after12 - 14 days of culture

\section{Callus and shoot induction media}

MS medium (Duchefa Biochemie), was supplemented with different concentrations of TDZ $(0$, $1,2,3$ and $\left.4 \mathrm{mgl}^{-1}\right)$ and $\mathrm{BA}\left(0,1,2,3\right.$ and $\left.4 \mathrm{mgl}^{-1}\right)$, each plant growth regulator (PGR) was applied alone and not in combination. Explants derived from in vitro seed culture plantlet, were grown in $250 \mathrm{~mL}$ glass jars covered with clear plastic caps. Each jar contained 30 $\mathrm{mL}$ medium.

\section{Explant preparation and culture}

Hypocotyls, cotyledon and leaf segments from 10 - 12 day-old in vitro raised seedlings were excised under aseptic conditions, the length of the hypocotyl (1 $\mathrm{cm})$, cotyledonary leaves $\left(0.5 \pm 0.5 \mathrm{~cm}^{2}\right)$ and leaf $(0.5$ $\pm 0.5 \mathrm{~cm}^{2}$ ) explants excised from four leaves in vitro seedlings grown from seeds. Hypocotyl explants were incubated horizontally, cotyledons and leaves incubated adaxial (upper surface facing down) (Bhatia et al., 2004) on callus and shoot induction media. Then, culture was kept at $24 \pm 2^{\circ} \mathrm{C}$ conditions under 16 $\mathrm{h}$ photoperiod, light intensity of $50 \mu \mathrm{mol} \mathrm{m}^{-2} \mathrm{~s}^{-1}$.

\section{Parameters evaluation and data analysis}

After 3 weeks of explant culture in callus and shoot regeneration media, data were observed at regular intervals. Scale rating from 0 to 5 was performed to set numerical values for callusing index. The scale was defined as following; " 0 - no tissue growth, 1- callus occurring from one explant end, 2callus occurring from both explant ends, 3- callus occurring from both explant ends and double the original explant size, 4- callus occurring from both explant ends and triple the original explant size and 5callus occurring from both explant ends and four times the original explant size"in addition data presented callus response \%. After 6 weeks from explant culture. The following shoot regeneration parameters were recorded: shoot regeneration \%, shoots number explant ${ }^{-1}$ and shoot length $\mathrm{cm}$.

\section{Root Induction}

The best elongated normal shoots, which have no roots, were sub cultured and planted again on full 
and half strength MS medium containing different concentrations of auxins IAA, IBA, NAA $(0,0.1,0.5$, 1.0 and $2.0 \mathrm{mgl}^{-1}$ ). (alone and not in combination) for root initiation. Data recorded included root initiation response (\%), of roots length (cm.) and number of roots $\operatorname{shoot}^{-1}$.

\section{Acclimization}

Eight weeks old rooted plantlets were acclimatized and out planted in pots contained peat moss and vermiculite (1: $1 \mathrm{v} / \mathrm{v})$ after washing agar thoroughly with running tap water. The pots were covered with clear plastic bags having a few holes and were frequently watered to keep high humidity during 20 days. Hardened plantlets were out planted in a greenhouse set at a day temperature $25^{\circ} \mathrm{C}$, a night temperature $18^{\circ} \mathrm{C}$, relative humidity $85 \%$ and a day length of $14 \mathrm{~h}$.

Mature seed derived plants were also grown under the same condition and the same time to compare the growth performance of in vitro plants with those of seed derived plants. The plantlets were irrigated immediately after planting and adequate soil moisture was maintained through daily watering and fertilized as the normal fertilizer program of commercial tomato plants. Data were recorded after 12 weeks from the initial culture in the greenhouse and the measurements included: Leaf number plant $^{-1}$, plant height $\mathrm{cm}$., number of nodes to first flower, number of raceme plant ${ }^{-1}$, number of flower raceme ${ }^{-1}$, number of fruit raceme ${ }^{-1}$ and total number of fruit plant ${ }^{-1}$ ).

Pots were randomly arranged on the green house benches with four replicates (pots) for each plant types (plants derived from in vitro shoot regeneration of petiole, cotyledon and leaf disc under different TDZ and BA concentrations) and from mature cherry tomato seeds.

\section{Statistical analysis}

All in vitro experiments were repeated twice with at least five replications. Data were combined and subjected to ANOVA using Costat computer program (CoStat Statistical Software; CoHort Soft-ware version 6.4, Berkeley, California) and the differences between means were separated using Duncan's multiple-range test at 5\% significance level.

\section{RESULTS AND DISCUSSION}

The in vitro morphogenetic responses of the cultured explants are affected by different components of the culture media and therefore, it is essential to evaluate their effects on plant callus induction and shoot regeneration (Gubis et al., 2004). In the current study callus was initiated within $8-12$ days directly on the cut surfaces of hypocotyl, cotyledon and leaf disc explants cultured on MS basal medium supplemented with different concentration of (TDZ and BA) alone, but not in hormone free- medium (Table 1). Callus response was markedly affected by types of explant and growth regulators used. Different concentrations of TDZ and BA had a distinct effect on callus induction from explants. Pal et al. (2007) reported that in vitro callus induction depends on the endogenous concentration of plant growth regulator as well as exogenously supplied growth regulator. Moreover, Nikam and Shitole (1998) reported that the growth regulator requirements for callus induction vary depending on the source of explant.

Table (1): Effect of different concentrations of benzyladenine (BA) and thidiazeron (TDZ) on callus induction of cherry tomato (Lycopersicon esculentum Mill., c.v. Summer Cherry)

\begin{tabular}{|c|c|c|c|c|c|c|c|c|}
\hline \multirow{2}{*}{$\begin{array}{r}\begin{array}{c}\text { Type of } \\
\text { explants }\end{array} \\
\text { PGR }\left(\mathrm{mgl}^{-1}\right)\end{array}$} & \multicolumn{4}{|c|}{ Callus response $\%$} & \multicolumn{4}{|c|}{ Callus index } \\
\hline & Hypocotyls & Cotyledon & $\begin{array}{l}\text { Leaf } \\
\text { disc }\end{array}$ & Mean & Hypocotyls & Cotyledon & $\begin{array}{l}\text { Leaf } \\
\text { disc }\end{array}$ & Mean \\
\hline \multicolumn{9}{|l|}{ TDZ } \\
\hline 0.5 & $55 \mathrm{~d}$ & $58.3 d$ & $55 \mathrm{~d}$ & 56.1 & $2.8 \mathrm{~b}$ & $1.8 \mathrm{c}$ & $1.6 \mathrm{c}$ & $2.1 \mathrm{~b}$ \\
\hline 1.0 & $100 \mathrm{a}$ & $75.0 \mathrm{c}$ & $95 a$ & 90.0 & $3.7 \mathrm{a}$ & $2.2 \mathrm{bc}$ & $2.3 \mathrm{ab}$ & $2.7 \mathrm{a}$ \\
\hline 2.0 & $100 \mathrm{a}$ & $86.6 b$ & $92 \mathrm{ab}$ & 92.9 & $3.9 \mathrm{a}$ & $2.1 \mathrm{bc}$ & $2.0 \mathrm{bc}$ & $2.7 \mathrm{a}$ \\
\hline 3.0 & $100 \mathrm{a}$ & $92.3 \mathrm{a}$ & $100 \mathrm{a}$ & 97.4 & $3.0 \mathrm{a}$ & $2.0 \mathrm{bc}$ & $2.4 \mathrm{ab}$ & $2.5 \mathrm{a}$ \\
\hline 4.0 & $100 \mathrm{a}$ & $60.3 \mathrm{de}$ & $100 \mathrm{a}$ & 86.8 & $2.2 \mathrm{bc}$ & $1.6 \mathrm{c}$ & $1.6 \mathrm{c}$ & $1.8 \mathrm{~b}$ \\
\hline Mean & $91 \mathrm{a}$ & $74.5 b$ & $88.4 \mathrm{ab}$ & & $3.12 \mathrm{a}$ & $1.94 b$ & $1.98 b$ & \\
\hline \multicolumn{9}{|l|}{$\mathbf{B A P}$} \\
\hline 0.5 & $67.9 \mathrm{c}$ & $51.0 \mathrm{~d}$ & $69.9 c$ & 62.9 & $3.5 \mathrm{a}$ & $0.0 \mathrm{~d}$ & $0.0 \mathrm{~d}$ & $1.2 \mathrm{c}$ \\
\hline 1.0 & $80.6 b$ & $91.6 \mathrm{a}$ & $82.6 b$ & 84.9 & $2.5 b$ & $1.9 \mathrm{c}$ & $1.8 \mathrm{c}$ & $2.1 \mathrm{~b}$ \\
\hline 2.0 & $100 \mathrm{a}$ & $66.6 \mathrm{~cd}$ & $80 \mathrm{a}$ & 82.2 & $2.0 \mathrm{bc}$ & $2.6 b$ & $3.1 \mathrm{a}$ & $2.6 \mathrm{a}$ \\
\hline 3.0 & $78.5 \mathrm{c}$ & $75.0 \mathrm{c}$ & $83.5 b$ & 79.0 & $2.7 b$ & $2.5 b$ & $2.9 \mathrm{ab}$ & $2.7 \mathrm{a}$ \\
\hline 4.0 & $72.5 \mathrm{c}$ & $48.0 \mathrm{e}$ & $74.5 \mathrm{c}$ & 65.0 & $2.7 \mathrm{~b}$ & $1.8 \mathrm{c}$ & $1.7 \mathrm{c}$ & $2.4 \mathrm{ab}$ \\
\hline Mean & $79.9 \mathrm{a}$ & $66.44 b$ & $78 \mathrm{a}$ & & $2.7 \mathrm{a}$ & $1.8 \mathrm{~b}$ & $1.9 \mathrm{~b}$ & \\
\hline
\end{tabular}

Data represent the mean of four replicates with six explants for each treatment. Means followed by same letter do not differ statistically at $\mathrm{p}=0.05$ according to the Duncan's multiple range test 
Our results indicated that the highest callusing index (3.9 and 3.7) was obtained on hypocotyl explant cultured on MS medium supplemented with TDZ at 1.0 and $2.0 \mathrm{mgl}^{-1}$ (Table 1), followed by (3.5) obtained from the same explant by using $0.5 \mathrm{mgl}^{-1}$ BA. However MS medium supplemented with BA at either 2.0 or $3.0 \mathrm{mgl}^{-1}$ presented the highest callusing index for both cotyledon and leaf disc explants. In general, it was found that hypocotyls produced the highest values of both callus response and callus index than cotyledons and leaf disc. Moreover, it was noticed that even though more callus were produced by hypocotyls, their shoot regeneration ability was lower than that produced by cotyledons and leaf disc explants (Table 2 ). These results are coherent with the findings of former investigations (Ali et al., 2012). A significant increment of callus proliferation was observed over the culture period. The origination of callus and shoots was noticed in the middle part of explants and on cut edges. In terms of morphology, the callus was fragile and characterized by a pale yellow or green color.

The primary mode of regeneration is shoot organogenesis, which can retrieve directly or indirectly from organ explants (Bhatia et al., 2004; Chaudhry et al., 2010). Most of the reports about shoot organogenesis in tomato are related to the induction of regeneration from hypocotyls or cotyledon explants (Asakura et al., 1995; Icjimura and Oda, 1995; Moghaleb et al., 1999). In this study, it was found that using hypocotyls, cotyledons and leaf discs as explants to study the effect of various concentrations of TDZ and BA for high cherry tomato regeneration frequencies. MS media containing BA and TDZ were tested individually for shoot induction. Generally, No responses were found in control medium without TDZ and BA. It shows that the presence of BA and TDZ is essential for shoot organogenesis. It was observed that all explants responded significantly to presence of TDZ and BA. However, the best responses to regeneration $(100 \%)$ was recorded on leaf disc and cotyledon at TDZ (2.0, 3.0 and $\left.4.0 \mathrm{mg}^{-1}\right)$ and BA $\left(2.0 \mathrm{mg}^{-1}\right)$. Hypocotyle showed the lowest regeneration $\%$ at different TDZ and BA concentration. (Figs. 2 (a,b), $3(a, b)$ and $4(a, b))$ are shown different regeneration responses among the three explants and two PGR (TDZ \& BA). These results are in agreement with Chaudhry et al. (2010), who have reported the best explants for regeneration are respectively leaf disc, cotyledon and hypocotyl. In addition, other reports indicated that cotyledon regenerated better than hypocotyls explants (Shutze and Wieczorrek, 1987; Hamza and Chupeau, 1993). However, Mohamed et al. (2011) have reported that there was no significant difference between cotyledon and hypocotyl explants in the same treatment on regeneration.

The highest number of shoots explant ${ }^{-1}$ (13.4) was observed in medium containing $2.0 \mathrm{mg} \mathrm{L}^{-1} \mathrm{TDZ}$ with a maximum in vitro shoot length of about $8 \mathrm{~cm}$. BA-supplemented medium produced 11.9 shoots explant $^{-1}$ at $3.0 \mathrm{mg} \mathrm{L}^{-1}$, and the highest shoot length of
$7.2 \mathrm{~cm}$ was observed at $2.0 \mathrm{mg} \mathrm{L}^{-1}$ (Table 2). Also, the best explant for shoot number explant ${ }^{-1}$ was the cotyledon, and highest shoot length was observed in leaf disc explant for both PGRs, (TDZ and BA) at different concentrations. These results are consistent with Chaudhry et al. (2010) who showed that the explant source had shown significantly different results for various hormones. The best shoot formation was found for cotyledon explant callus induced and sub cultured on MS medium containing TDZ at 2.0 and 3.0 $\mathrm{mgl}^{-1}$. The requirement of cytokinin for shoot initiation is well established (Beck and Coponetti, 1983; Evans et al., 1984). In this investigate; TDZ presented the greatest result for shoot organogenesis than BA. TDZ, a synthetic phenylurea, is considered to be one of the most active cytokinins for shoot induction in plant tissue culture (Huetteman and Preece, 1993). Many reports confirmed that TDZ produces shoot regeneration better than other cytokinins (Thomas, 2003; Thomas and Puthur, 2004; Husain et al., 2007). In other study, Mok et al. (1982), confirmed that TDZ is involved in cytokinin metabolism. TDZ has been exposed to stimulate accumulation of endogenous cytokinins (Murthy et al., 1995; Hutchinson et al., 1996). Furthermore to the cytokinin-like activity, Hutchinson et al. (1996) detected that, TDZ stimulated auxin accumulation. Other studies showed that TDZ affected auxin transport in hypocotyl tissues of Pelargonium hortorum (Murch and Saxena, 2001) and promoted the regeneration frequency by altering the levels of abscisic acid (Li and Yang, 1988), ethylene (Yip and Yang, 1986) and proline (Murch and Saxena, 1997). On the other hand, the mechanism of TDZ action in plant regeneration in vitro is not clear.

In this experiment, the best callus induction was achieved on hypocotyl explant. However, the leaf disc followed by cotyledon had better performance in shoot regeneration through callus than hypocotyl explant, indicating that, the cotyledonary and leaf disc tissue of tomato is an excellent explant for plant regeneration. Previous studies demonstrated that cotyledons and leaf disc of tomato were better to other sources of explants, including hypocotyls and stems, for promoting shoot organogenesis of tomato (Hamza and Chupeau, 1993; Van Roekel et al., 1993; Ling et al., 1998).

Induction of roots on regenerated shoots is important for effective establishment of the plantlet on the soil. Half strength MS was the best tomato rooting medium supplemented with any of the synthetic hormones (Table 3). In uniformity with our result, Devi et al. (2008) reported that the best tomato rooting was obtained on half strength MS basal medium. The highest mean number of rootsshoot $^{-1}$ (22.5) was noticed on half strength MS supplemented with IAA at $1.0 \mathrm{mgl}^{-1}$ (Fig. 5a,b), and longest root $(11 \mathrm{~cm})$ seen in the same medium containing IBA at $2.0 \mathrm{mg} / \mathrm{l}$. Our results indicated that $90 \%$ rooting was found on half strength MS basal medium without growth regulator, indicating that this tomato genotype possessed sufficient level of endogenous auxin. 


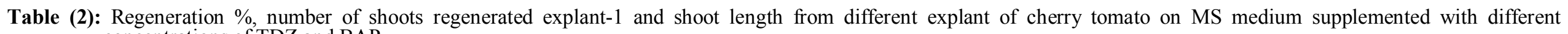
concentrations of TDZ and BAP

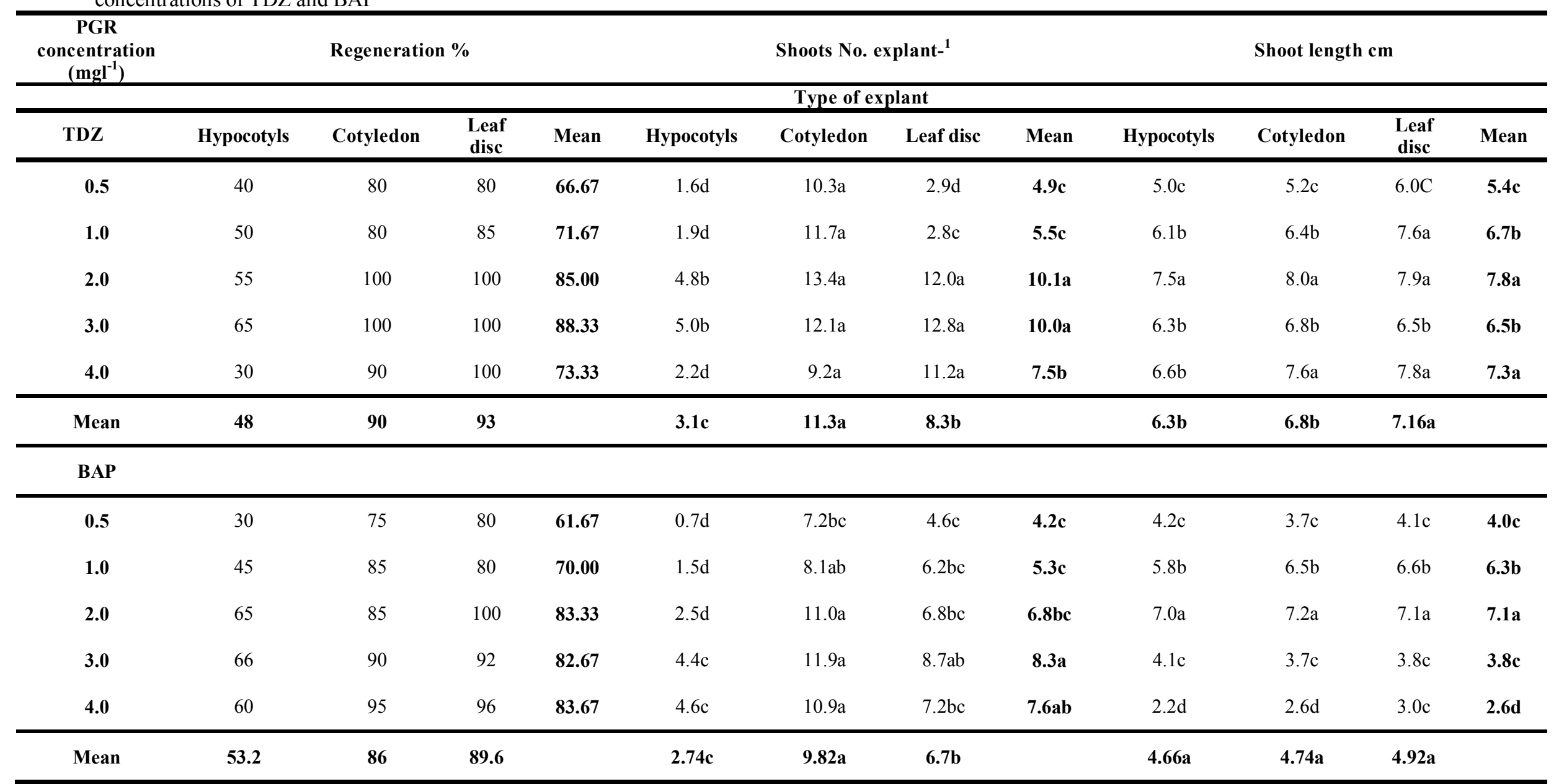

Data represent the mean of four replicates with six explants for each treatment. Means followed by same letter do not differ statistically at $\mathrm{p}=0.05$ according to the Duncan's multiple range test 


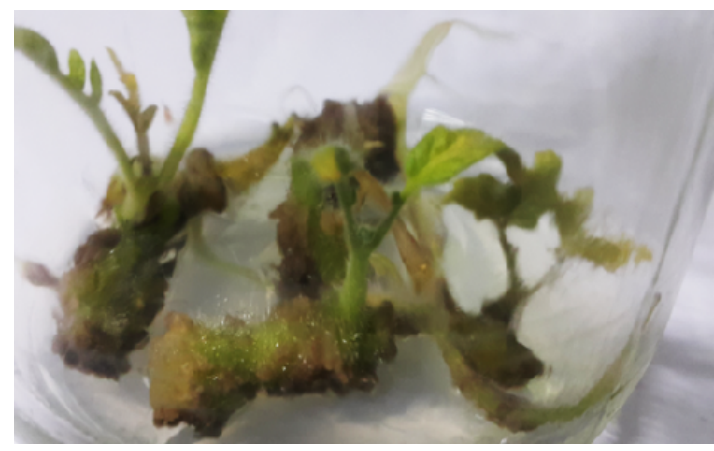

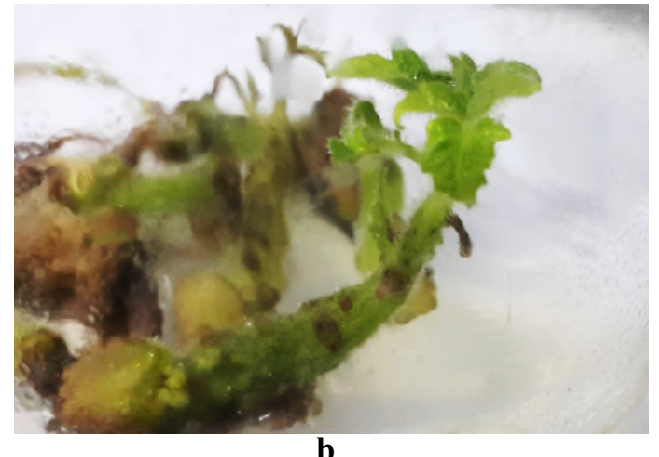

Fig (2): Callus formation and shoot regeneration from Hypoctyle explant in MS media with $3.0 \mathrm{mgl}^{-1} \mathrm{BA}$. (a). and MS media with $3.0 \mathrm{mgl}^{-1} \mathrm{TDZ}(\mathrm{b})$

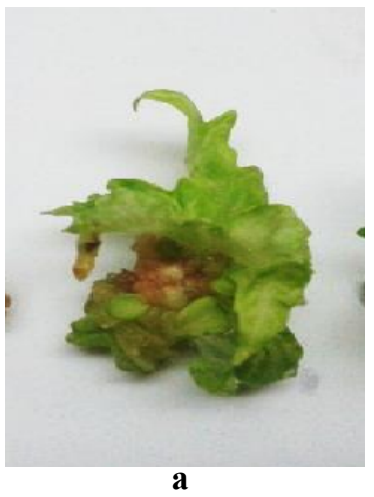

a



b

Fig (3): Shoot regeneration from cotyledon explant on (a) MS containing $3.0 \mathrm{mgl}^{-1} \mathrm{BA}$. and on (b) MS containing 3.0 $\mathrm{mgl}^{-1} \mathrm{TDZ}$

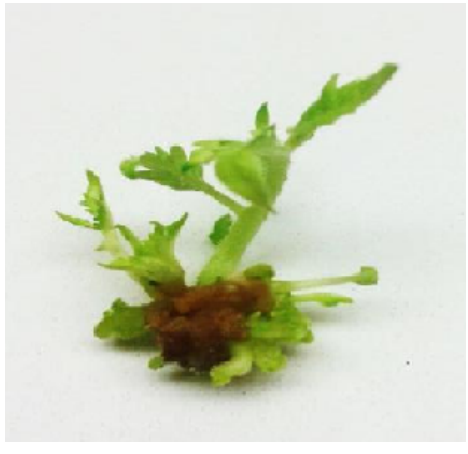

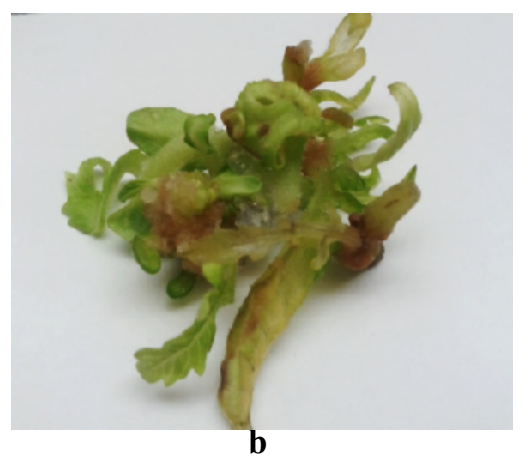

Fig (4): Shoot regeneration from leaf disc explant on (a) MS containing $3.0 \mathrm{mgl}^{-1} \mathrm{BA}$. and on (b) MS containing $3.0 \mathrm{mgl}^{-}$ ${ }^{1} \mathrm{TDZ}$

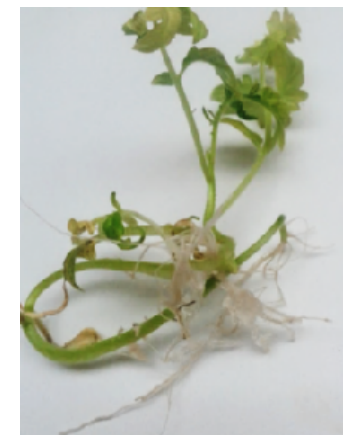

Fig (5. a): Rooting of elongated shoots on MS medium with $1.0 \mathrm{mgl}^{-1} \mathrm{IAA}$

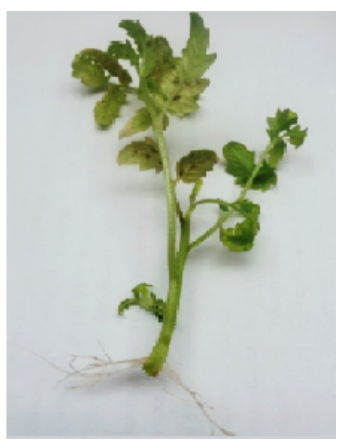

Fig (5.b): Rooting of elongated shoots on MS medium with $1.0 \mathrm{mgl}^{-1}$ IBA 
Table (3): Effect of different concentrations of auxins and MS salt strength on rooting percentage, number of root per shoot and root length in tomato (Lycopersicon esculentum Mill., c.v. Summer Cherry)

\begin{tabular}{|c|c|c|c|c|c|c|c|c|}
\hline \multirow{2}{*}{\multicolumn{3}{|c|}{ PGR }} & \multicolumn{6}{|c|}{ Medium } \\
\hline & & & \multicolumn{3}{|c|}{ Full MS } & \multicolumn{3}{|c|}{$1 / 2$ MS } \\
\hline IAA & IBA & NAA & $\begin{array}{c}\text { Response } \\
(\%)\end{array}$ & $\begin{array}{c}\text { Average } \\
\text { no. of } \\
\text { roots }\end{array}$ & $\begin{array}{l}\text { Average } \\
\text { length of } \\
\text { roots cm. }\end{array}$ & $\begin{array}{c}\text { Response } \\
(\%)\end{array}$ & $\begin{array}{c}\text { Average } \\
\text { no. of } \\
\text { roots }\end{array}$ & $\begin{array}{l}\text { Average } \\
\text { length of } \\
\text { roots cm. }\end{array}$ \\
\hline 0.0 & & & 55.3 & 6.8ghi & $6.6 \mathrm{fgh}$ & 92 & $8.5 \mathrm{fg}$ & $7.4 \mathrm{ef}$ \\
\hline 0.1 & & & 96 & $11.5 \mathrm{ef}$ & $5.6 \mathrm{ij}$ & 100 & $8.5 \mathrm{fg}$ & $8.5 \mathrm{dc}$ \\
\hline 0.5 & & & 100 & $12.5 \mathrm{e}$ & $4.8 \mathrm{jk}$ & 100 & $12.5 \mathrm{e}$ & $7.5 \mathrm{ef}$ \\
\hline 1.0 & & & 100 & $15.5 \mathrm{~cd}$ & $3.9 \mathrm{kl}$ & 100 & $22.5 \mathrm{a}$ & $8.0 \mathrm{de}$ \\
\hline \multirow[t]{9}{*}{2.0} & & & 100 & $15.0 \mathrm{~d}$ & $3.0 \mathrm{~lm}$ & 100 & $20.5 \mathrm{ab}$ & $8.0 \mathrm{de}$ \\
\hline & 0.1 & & 96 & 5.3hi & $10.0 \mathrm{~b}$ & 100 & $6.5 \mathrm{ghi}$ & $9.0 \mathrm{c}$ \\
\hline & 0.5 & & 98 & $7.5 \mathrm{ghi}$ & $6.5 \mathrm{ghi}$ & 100 & $7.5 \mathrm{ghi}$ & $10.2 b$ \\
\hline & 1.0 & & 100 & $17.0 \mathrm{~cd}$ & 6.6fghi & 100 & $8.0 \mathrm{gh}$ & $10.0 \mathrm{~b}$ \\
\hline & 2.0 & & 90 & $11.5 \mathrm{ef}$ & 5.9hi & 100 & $8.8 \mathrm{fg}$ & $11.0 \mathrm{a}$ \\
\hline & & 0.1 & 100 & $17.8 \mathrm{~cd}$ & 3.71 & 100 & $18.5 b c$ & $6.0 \mathrm{hi}$ \\
\hline & & 0.5 & 96 & $16.5 \mathrm{~cd}$ & $2.91 \mathrm{~m}$ & 100 & $21.0 \mathrm{a}$ & $3.0 \mathrm{~lm}$ \\
\hline & & 1.0 & 80 & $9.0 \mathrm{fg}$ & $1.0 \mathrm{n}$ & 100 & $18.0 \mathrm{~cd}$ & $2.6 \mathrm{~m}$ \\
\hline & & 2.0 & 65 & $4.5 \mathrm{i}$ & $0.7 \mathrm{n}$ & 100 & $9.0 \mathrm{fg}$ & $1.3 \mathrm{n}$ \\
\hline
\end{tabular}

Data represent the mean of four replicates with six explants for each treatment. Means followed by same letter do not differ statistically at $\mathrm{p}=0.05$ according the Duncan's multiple range test

\section{Acclimatization}

Meanwhile in vitro rooted plantlet are raised in the most congenial environmental conditions, hardening is necessary to ensure survival of the micro propagated plants upon transfer to soil under natural conditions. Therefore, in vitro rooted plantlets with 3 to 4 fully expanded leaves and well developed roots derived from different explant and different concentration of TDZ and BA were transferred to pots filled with peat moss and vermiculite. The percentage of survived plantlets after shifting to peat moss was $100 \%$. These grew well and were transferred to the greenhouse condition. Seed-derived plants of the same genotype were also grown in the same time under the same condition to compare the ex vitro growth performance of in vitro propagated plants with those of seed derived plants. No abnormal phenotype was observed during the test period which terminated after 12 weeks from transferring those plants from culture jars to the greenhouse. Data on growth performance ex vitro are presented in (Table 4) Results presented that cherry tomato derived from different explant sources under different concentration of TDZ and BA were not significantly different in their vegetative characters (leaf number plant-1, plant height $\mathrm{cm}$. and number of nodes to first flower) to those obtained from seed, as shown in (Table 4). However Results showed that cherry tomato derived from different explant sources under different concentration of TDZ and BA were significantly different in number of (raceme plant ${ }^{-1}$, flower raceme-1, fruit raceme-1, fruit plant $^{-1}$ ) when compared to seed-derived plants. From the result in (Table 4), data presented that number of (raceme plant ${ }^{1}$, flower raceme ${ }^{-1}$, fruit raceme ${ }^{-1}$, fruit plant $^{-1}$ ) which produced by seed-derived plants was significantly less than those derived from in vitro propagated plants. In the present study, tissue culture propagated tomatoes plants showed normal growth performance and continued their growth until flowering and fruiting. This stability in growth behavior may be due to the short growth cycle under the in vitro condition of this study as regenerates were exposed only to one subculture. The obtained results are in agreement with (Ali et al., 2012; Wayase and Shitole, 2014), which showed that the increase in the number of subcultures enhances the rate of off-type plants. The present investigation demonstrated that a dedifferentiated propagation route via de novo shoots development in Solanum lycopersicum L. var. cerasiforme could be used for large scale multiplication and future genetic transformation techniques. 
Table (4): Ex vitro reproductive growth performance of cherry tomato derived from in vitro regenerated hypocotyl, cotyledon and leaf disc or seedlings (after 12 weeks from transferring those plants from culture jars to the greenhouse)

\begin{tabular}{|c|c|c|c|c|c|c|c|c|c|c|c|c|}
\hline \multirow{3}{*}{ Growth Performance } & \multicolumn{11}{|c|}{ Plantlet derived from Hypocotyls } & \multirow{3}{*}{ Seed } \\
\hline & \multicolumn{5}{|c|}{${\mathrm{TDZ} \mathrm{mgl}^{-1}}^{-1}$} & \multicolumn{5}{|c|}{$\mathrm{BAmgl}^{-1}$} & \multirow{2}{*}{ Mean } & \\
\hline & 0.5 & 1.0 & 2.0 & 3.0 & 4.0 & 0.5 & 1.0 & 2.0 & 3.0 & 4.0 & & \\
\hline Leaf number plant $^{-1}$ & $35.8 b$ & $36.1 \mathrm{~b}$ & $35.0 \mathrm{~b}$ & $35.5 b$ & $43.8 \mathrm{a}$ & $36.0 \mathrm{~b}$ & $36.2 b$ & $36.1 \mathrm{~b}$ & $35.9 \mathrm{~b}$ & $35.4 \mathrm{~b}$ & $36.6 \mathrm{a}$ & $36.7 \mathrm{a}$ \\
\hline Plant height $\mathrm{cm}$. & $160.0 \mathrm{~b}$ & $164.0 \mathrm{ab}$ & $160.0 \mathrm{~b}$ & $164.8 \mathrm{ab}$ & $166.0 \mathrm{a}$ & $167.0 \mathrm{a}$ & $166.0 \mathrm{a}$ & $166.1 \mathrm{a}$ & $165.8 \mathrm{a}$ & $163.0 \mathrm{~b}$ & $164.3 \mathrm{a}$ & $165.0 \mathrm{a}$ \\
\hline No. of nodes to first flower & $9.0 \mathrm{ab}$ & $10.6 \mathrm{a}$ & $10.0 \mathrm{a}$ & $10.0 \mathrm{a}$ & $10.0 \mathrm{a}$ & $9.5 \mathrm{a}$ & $9.8 \mathrm{a}$ & $9.9 .0 \mathrm{a}$ & $10.0 \mathrm{a}$ & $10.0 \mathrm{a}$ & $10.0 \mathrm{a}$ & $10.0 \mathrm{a}$ \\
\hline No. of raceme plant ${ }^{-}$ & $20.1 \mathrm{ab}$ & $20.8 \mathrm{a}$ & $20.0 \mathrm{ab}$ & 21.0a & $20.7 \mathbf{a}$ & $20.0 \mathrm{ab}$ & $20.0 \mathrm{ab}$ & $20.6 a$ & $19.9 \mathrm{ab}$ & $20.0 \mathrm{ab}$ & $20.31 \mathrm{a}$ & $18.0 \mathrm{~b}$ \\
\hline No. of flower raceme $e^{-1}$ & $31.0 \mathrm{~b}$ & $33.0 \mathrm{a}$ & $32.0 \mathrm{ab}$ & $33.4 \mathrm{a}$ & $34.8 \mathrm{a}$ & $32.0 \mathrm{ab}$ & $33.2 \mathrm{a}$ & $32.0 \mathrm{ab}$ & $32.0 \mathrm{ab}$ & $33.7 \mathrm{a}$ & $32.7 \mathrm{a}$ & $32.0 \mathrm{ab}$ \\
\hline No. of fruit raceme $e^{-1}$ & $10.0 \mathrm{ab}$ & 11.0a & $11.2 \mathrm{a}$ & $10.0 \mathrm{ab}$ & $9.6 \mathrm{ab}$ & $8.7 \mathrm{~b}$ & $10.0 \mathrm{ab}$ & $9.2 \mathrm{~b}$ & $10.0 \mathrm{ab}$ & $10.0 \mathrm{ab}$ & $9.97 \mathrm{a}$ & $8.0 \mathrm{~b}$ \\
\hline Total number of fruit plant ${ }^{-1}$ & $139.0 \mathrm{a}$ & $139.0 \mathrm{a}$ & $140.0 \mathrm{a}$ & $139.0 \mathrm{a}$ & $136.0 \mathrm{ab}$ & $134.0 \mathrm{~b}$ & $139.0 \mathrm{a}$ & $138.0 \mathrm{a}$ & $137.0 \mathrm{ab}$ & $140.0 \mathrm{a}$ & $138.1 \mathrm{a}$ & $130.0 \mathrm{~b}$ \\
\hline \multirow{3}{*}{ Growth Performance } & \multicolumn{11}{|c|}{ Plantlet derived from Cotyledon } & \multirow{3}{*}{ Seed } \\
\hline & & & $\mathrm{TDZ} \mathrm{mgl}^{-1}$ & & & & & BAmgl $^{-1}$ & & & Moon & \\
\hline & 0.5 & 1.0 & 2.0 & 3.0 & 4.0 & 0.5 & 1.0 & 2.0 & 3.0 & 4.0 & Mean & \\
\hline Leaf number plant ${ }^{-1}$ & $35.8 \mathrm{a}$ & $36.1 \mathrm{a}$ & $35.0 \mathrm{a}$ & $35.5 \mathrm{a}$ & $34.8 \mathrm{ab}$ & $36.0 \mathrm{a}$ & $36.2 \mathrm{a}$ & $36.1 \mathrm{a}$ & $35.9 \mathrm{a}$ & $35.4 \mathrm{a}$ & $35.7 \mathrm{a}$ & $36.7 \mathrm{a}$ \\
\hline Plant height $\mathbf{c m}$. & $166.0 \mathrm{a}$ & $164.0 \mathrm{ab}$ & $164.2 \mathrm{ab}$ & $164.8 \mathrm{ab}$ & $166.0 \mathrm{a}$ & $167.0 \mathrm{a}$ & $166.0 \mathrm{a}$ & $166.1 \mathrm{a}$ & $165.8 \mathrm{a}$ & $163.0 \mathrm{ab}$ & $165.3 \mathrm{a}$ & $165.0 \mathrm{a}$ \\
\hline No. of nodes to first flower & $9.6 \mathrm{a}$ & $10.6 \mathrm{a}$ & $10.0 \mathrm{a}$ & $10.0 \mathrm{a}$ & $10.0 \mathrm{a}$ & $9.5 \mathrm{a}$ & $9.8 \mathrm{a}$ & $9.9 \mathrm{a}$ & $10.0 \mathrm{a}$ & $10.0 \mathrm{a}$ & $9.9 \mathrm{a}$ & $10.0 \mathrm{a}$ \\
\hline No. of raceme plant ${ }^{-}$ & $19.1 \mathrm{ab}$ & $19.8 \mathrm{a}$ & $19.0 \mathrm{ab}$ & 20.0a & $19.7 \mathrm{ab}$ & $19.0 \mathrm{ab}$ & $19.0 \mathrm{ab}$ & $19.6 \mathrm{ab}$ & $18.9 \mathrm{ab}$ & $19.0 \mathrm{ab}$ & $19.3 \mathrm{a}$ & $18.0 \mathrm{~b}$ \\
\hline No. of flower raceme ${ }^{-1}$ & $32.0 \mathrm{ab}$ & 34.0a & $32.0 \mathrm{ab}$ & $33.4 \mathrm{a}$ & $34.8 \mathrm{a}$ & $32.0 \mathrm{ab}$ & $33.2 \mathrm{a}$ & $32.0 \mathrm{ab}$ & $33.0 \mathrm{ab}$ & $33.7 \mathrm{a}$ & $33.0 \mathrm{a}$ & $32.0 \mathrm{ab}$ \\
\hline No. of fruit raceme $e^{-1}$ & $9.3 \mathrm{ab}$ & $10.5 \mathrm{a}$ & $10.6 \mathrm{a}$ & $9.5 \mathrm{ab}$ & $8.4 \mathrm{ab}$ & $7.9 \mathrm{~b}$ & $9.9 \mathrm{a}$ & $9.2 \mathrm{ab}$ & $10.0 \mathrm{a}$ & $9.0 \mathrm{ab}$ & $9.4 \mathrm{a}$ & $8.0 \mathrm{~b}$ \\
\hline \multirow[t]{2}{*}{ Total number of fruit plant ${ }^{-1}$} & $140.0 \mathrm{a}$ & $140.2 \mathrm{a}$ & $140.0 \mathrm{a}$ & $139.3 \mathrm{a}$ & $136.8 \mathrm{ab}$ & $134.9 \mathrm{~b}$ & $139.5 \mathrm{a}$ & $138.7 \mathrm{a}$ & $137.5 \mathrm{ab}$ & $140.0 \mathrm{a}$ & $140.0 \mathrm{a}$ & $130.0 \mathrm{~b}$ \\
\hline & \multicolumn{11}{|c|}{ Plantlet derived from Leaf disc } & \multirow{3}{*}{ Seed } \\
\hline \multirow[t]{2}{*}{ Growth Performance } & \multicolumn{5}{|c|}{${\text { TDZ } \mathrm{mgl}^{-1}}^{-1}$} & & & BAmgl $^{-1}$ & & & \multirow{2}{*}{ Mean } & \\
\hline & 0.5 & 1.0 & 2.0 & 3.0 & 4.0 & 0.5 & 1.0 & 2.0 & 3.0 & 4.0 & & \\
\hline Leaf number plant ${ }^{-1}$ & $35.8 \mathrm{a}$ & $36.1 \mathrm{a}$ & $36.0 \mathrm{a}$ & $35.5 \mathrm{a}$ & $34.8 \mathrm{ab}$ & $36.0 \mathrm{a}$ & $36.2 \mathrm{a}$ & $36.1 \mathrm{a}$ & $36.9 \mathrm{a}$ & $35.4 \mathrm{a}$ & $35.9 \mathrm{a}$ & $36.7 \mathrm{a}$ \\
\hline Plant height $\mathrm{cm}$. & $165.0 \mathrm{a}$ & $164.8 \mathrm{ab}$ & $164.5 \mathrm{ab}$ & $164.9 \mathrm{a}$ & $165.5 \mathrm{a}$ & $166.0 \mathrm{a}$ & $166.1 \mathrm{a}$ & $165.8 \mathrm{a}$ & $166.0 \mathrm{a}$ & $164.0 \mathrm{ab}$ & $165.3 \mathrm{a}$ & $165.0 \mathrm{a}$ \\
\hline No. of nodes to first flower & $10.0 \mathrm{a}$ & $10.2 \mathrm{a}$ & $10.0 \mathrm{a}$ & $10.0 \mathrm{a}$ & $10.0 \mathrm{a}$ & $10.0 \mathrm{a}$ & $9.9 \mathrm{a}$ & $9.7 \mathrm{a}$ & $10.0 \mathrm{a}$ & $10.0 \mathrm{a}$ & $10.0 \mathrm{a}$ & $10.0 \mathrm{a}$ \\
\hline No. of raceme plant ${ }^{-}$ & $19.1 \mathrm{ab}$ & $19.8 \mathrm{a}$ & $19.0 \mathrm{ab}$ & 20.0a & $19.7 \mathrm{ab}$ & $19.0 \mathrm{ab}$ & $19.0 \mathrm{ab}$ & $19.6 \mathrm{ab}$ & $18.9 \mathrm{ab}$ & $19.0 \mathrm{ab}$ & $19.3 \mathrm{a}$ & $18.0 \mathrm{~b}$ \\
\hline No. of flower raceme ${ }^{-1}$ & $32.0 \mathrm{ab}$ & 34.0a & $32.0 \mathrm{ab}$ & $33.4 \mathrm{a}$ & $34.8 \mathrm{a}$ & $32.0 \mathrm{ab}$ & $33.2 \mathrm{a}$ & $32.0 \mathrm{ab}$ & $33.0 \mathrm{ab}$ & $33.7 \mathrm{a}$ & $33.0 \mathrm{a}$ & $32.0 \mathrm{ab}$ \\
\hline No. of fruit raceme $e^{-1}$ & $9.3 \mathrm{ab}$ & $10.6 \mathrm{a}$ & $10.0 \mathrm{a}$ & $9.3 \mathrm{ab}$ & $7.4 \mathrm{~b}$ & $8.9 \mathrm{ab}$ & $10.0 \mathrm{a}$ & $9.2 \mathrm{ab}$ & $10.1 \mathrm{a}$ & $10.4 \mathrm{a}$ & $9.5 \mathrm{a}$ & $8.0 \mathrm{~b}$ \\
\hline Total number of fruit plant ${ }^{-1}$ & $140.0 \mathrm{a}$ & $140.5 a$ & $140.7 \mathrm{a}$ & $139.9 \mathrm{a}$ & $137.8 \mathrm{ab}$ & $134.5 \mathrm{~b}$ & $138.5 \mathrm{a}$ & $139.7 \mathrm{a}$ & $140.5 \mathrm{a}$ & $142.0 \mathrm{a}$ & $139.4 \mathrm{a}$ & $130.0 \mathrm{~b}$ \\
\hline
\end{tabular}




\section{CONCLUSION}

In conclusion, the results verified during the present study clearly suggest that cotyledon explant achieved from 10 - 12 day-old seedlings of cherry tomato are very important for efficient shoot regeneration. Also, the present study underlines the importance of inclusion of TDZ in cherry tomato regeneration media. Furthermore, the present callus induction regeneration system would be valuable for genetic transformation and also has considerable potential to study somaclonal variation as an alternative mean of conventional hybridization.

Cherry tomato plants derived from rooted plantlets of callus regenerated in vitro were morphologically true to type. This indicate the possibility of using this system for secure micropropagation of valuable genotypes or breeding lines and hybrids in short time which might accelerate the breeding efforts of tomato plants.

\section{REFERENCES}

Afroz, A., Z. Chaudhry, U. Rashid, M. R. Khan and G. M. Ali (2010). Enhanced regeneration in explants of tomato (Lycopersicon esculentum L.) with the treatment of coconut water, Afr. J. Biotechnol., 9(24): 3634-3644.

Ali, A. A., T. R. Yossef and A. El-Banna (2012). Cytokinin interaction ameliorates the callus induction and plant regeneration of tomato (Solanum lycopersicum Mill.). Acta Agronomica Hungarica, 60: 47-55.

Asakura, N., S. Misoo, O. Kamijima and M. Sawano (1995). High frequency regeneration of diploids from apical end of cultured hypocotyl tissue in tomato, Breed. Sci., 45: 455-459.

Beck, M. J. and J. D. Caponetti (1983). The effects of kinetin and naphthalene acetic acid on in vitro shoot multiplication and rooting in the fish tail fern. Am. J. Bot., 70: 1-7.

Bhatia, P., N. Ashwath, T. Senaratna and D. Midmore (2004). Tissue culture studies of tomato (Lycopersicum esculentum). Plant Cell Tissue and Organ Culture, 78: 1-21.

Block, G. B., B. Patterson and A. Subar (1992). Fruit, vegetables and cancer prevention, a review of the epidemiological evidence. Nutr. Cancer, 18: $1-29$.

Brichkova, G. G., T. V. Maneshina and N. A. Kartel (2002). Optimization of the nutrient medium for effective regeneration of tomatoes (Lycopersicon esculentum Mill.) in vitro. VestsiNatsyyanal'nai-AkademiiNavukBelarusi.-Seryya-Biyalagichnykh Navuk, 2: 47-52.

Chaudhry, Z., S. Abbas, A. Yasmin, H. Rashid, H. Ahmed and M. A. Anjum (2010). Tissue culture studies in tomato (Lycopersicon esculentum) var. Moneymaker, Pak. J. Bot., 42(1): 155-163.

Devi, R., M. S. Dhailwal, A. Kaur and S. S. Gosal (2008). Effects of growth regulators on in vitro micropropegenic response of tomato. Indian J. Biotechnol., 7: 526-530.

FAOSTAT (2016). Food and Agriculture Organization of the United Nations, Rome, Italy. (http://faostat.fao.org).

Evans, D. A., W. R. Sharp and J. E. Bravo (1984). Cell culture methods for crop improvement. In: Sharp, W. R., D. A. Evans, P. V. Ammirato and Y. Yamada (Eds.). Hand Book of Plant Cell Culture. Macmillan Publishing Company, New York. Vol. 2.

Franklin, C. I. and R. A. Dixon (1994). Initiation and maintenance of callus and cell suspension cultures, Plant Cell Culture - a Practical Approach, Dixon, R.A. and Gonzales, R.A., Eds., New York: Oxford Univ. Press, $2^{\text {nd }}$ ed., pp. $1-29$.

Gerster, H. (1997). The potential role of lycopene for human health. J. Am. Coll. Nutr., 16: 109126.

Gubis, J., Z. Lajchova, J. Farago and Z. Jurekova (2004). Effect of growth regulators on shoot induction and plant regeneration in tomato (Lycopersicon esculentum Mill.), Biologia (Bratislava), 59(3): 405-408.

Hamza, S. Y. and R. E. Chupeau (1993). evolution of conditions for plant regeneration and Agrobacterium mediated transformation from tomato (Lycopersicon esculentum), J. Exp. Bot., 44: 1837-1845.

Huetteman, C. A. and J. E. Preece (1993). Thidiazuron: a potent cytokinin for woody plant tissue culture. Plant Cell, Tissue Organ. Cult., 33: 105- 109.

Husain, M. K., M. Anis and A. Shahzad (2007). In vitro propagation of Indian Kino (Pterocarpus marsupium Roxb.) using thidiazuron. In Vitro: Cell. Dev. Biol. Plant, 43: 59-64.

Hutchinson, M. J., S. J. Murch and P. K. Saxena (1996). Morphoregulatory role of thidiazuron: evidence of the involvement of endogenous auxin in thidiazuron-induced somatic embryogenesis of geranium (Pelargonium hortorum Bailey). J. Plant Physiol., 149: 573579.

Ichjimura, K. and M. Oda (1995). Stimulation of shoot regeneration from cotyledon segments of tomato (Lycopersicon esculentum Mill.) by agar and its extract, J. Jpn. Soc. Hortic. Sci., 64: 135-141.

Jabeen, N., Z. Chaudhry, H. Rashid and B. Mirza (2005). Effect of genotype and explant type on in vitro shoot regeneration of tomato (Lycopersicon esculentum), Pak. J. Bot., 37(4): 899-903.

Jiang, B. O., Y. Ying-Gen, G. Yi-Ming, G. ZhongChen and C. Yong-Zhe (2005). Thidiazuroninduced in vitro shoot organogenesis of the medicinal plant Arnebia euchroma (royle) johnst. In Vitro: Cell. Dev. Biol. Plant., 41: 677-681. 
Kaeppler, S. M., H. F. Kaeppler and Y. Rhee (2000). Epigenetic aspects of somaclonal variation in plants. Plant Mol. Biol., 43: 179-188.

Li, Z. L. and S. Y. Yang (1988). Reduction of abscisic acid and induction of sprouting in potato Solanum tuberosum L. by TDZ. J. Plant Growth Regul., 7: 37-44.

Ling, H. Q., D. Kriseleit and M. W. Ganal (1998). Effect of ticarcillin/potassium clavulanate on callus growth and shoot regeneration in Agrobacterium mediated transformation of tomato (Lycopersicon esculentum Mill.). Plant Cell Rep. 17: 843-847.

Liza, L. N., A. N. M. Nasar, K. M. A. Zinnah, M. AlNayem Chowdhury and M. Ashrafuzzaman (2013). In vitro growth media effect for regeneration of tomato (Lycopersicon esculentum) and evaluation of the salt tolerance activity of callus. J. Agric. Sustain., 3: $132-143$.

Moghaleb, R. E. A., H. Saneoka and K. Fujita (1999). Plant regeneration from hypocotyls and cotyledon explants of tomato (Lycopersicon esculentum), Soil Sci. Plant Nutr., 45: 639646.

Mohamed, A. N., M. R. Ismail, M. A. Kadir and H. M. Saud (2011). In vitro performances of hypocotyl and cotyledon explants of tomato cultivars under sodium chloride stress, Afr. J. Biotechnol., 10(44): 8757-8764.

Mohamed, A. N., M. R. Ismail and M. H. Rahman (2010). In vitro response from cotyledon and hypocotyls explants in tomato by inducing 6benzylaminopurine. Afr. J. Biotechnol., 9: 4802-4807.

Mok, M. C., D. W. S. Mok, D. J. Armstrong, K. Shudo, Y. Isogai and T. Okamoto (1982). Cytokinin activity of N-phenyl-N0-1, 2, 3thidiazol-5-yl urea (thidiazuron). Phytochemistry, 21: 1509-1511.

Murashige, T. and A. Skoog (1962). A revised medium for rapid growth and bioassays with tobacco tissue cultures. Physiol. Plant., 15: 473-497.

Murch, S. J. and P. K. Saxena (1997). Modulation of mineral and fatty acid profiles during thidiazuron mediated somatic embryogenesis in peanuts (Arachis hypogeae L.). J. Plant Physiol., 151: 183-191.

Murch, S. J. and P. K. Saxena (2001). Molecular fate of thidiazuron and its effects on auxin transport in hypocotyl tissues of Pelargonium $£$ hortorum Bailey. Plant Growth Regul., 35: 269-275.
Murthy, B. N. S., S. J. Murch and P. K. Saxena (1995). TDZ-induced somatic embryogenesis in intact seedlings of peanut (Arachis hypogaea): endogenous growth regulator levels and significance of cotyledons. Physiol. Plant. 94: 268-276.

Nikam, T. D. and M. G. Shitole (1998). In vitro culture of safflower L. cv. Bhima. Initiation, growth optimization and organogenesis. Plant Cell Tissue Organ. Cult., 55: 15-22.

Pal, S. P., I. Alam, M. Anisuzzaman, K. K. Sarker, S. A. Sharmin and M. F. Alm (2007). Indirect organogenesis in summer squash (Cucurbita pepo 1.). Turk. J. Agric. For., 31: 63-70.

Rao, A. and S. Agarwal (2000). Role of antioxidant lycopene in cancer and heart disease. J. Am. College Nutr., 19: 563-569.

Raziuddin, S., H. J. Salim, T. Chaudhary, A. Mohammad and S. Ali (2004). Hormonal effect on callus induction in tomato. Sarhad J. Agric., 20: 223-225.

Shutze, R. and G. Wieczorrek (1987). Investigations into tomato tissue cultures. I. Shoot regeneration in primary explants of tomato, Arch. Zuchtungsforsch., 17: 3-15.

Thomas, T. D. (2003). Thidiazuron induced multiple shoot induction and plant regeneration from cotyledonay explants of mulberry. Biol. Plant., 46: 529-533.

Thomas, T. D. and J. T. Puthur (2004). Thidiazuron induced high frequency shoot organogenesis in callus from Kigeliapinnata L. Bot. Bull. Acad. Sin., 45: 307-313.

Tomsone, S., D. Gertnere and D. Novikova (2004). The influence of thidiazuron on Shoot regeneration and proliferation of rhododendrons in vitro. Acta Universit. Latviensis Biol., 676: 239-242.

Van Roekel, J. S. C., B. Damm, L. S. Melchers and A. Hoekema (1993). Factors influencing transformation frequency of tomato, Plant Cell Rep., 12: 644-647.

Wayase, U. R. and M. G. Shitole (2014). Effect of plant growth regulators and organogenesis in tomato (Lycopersicon esculentum Mill.) cv. Dhanashri. International Journal of Pure and Applied Sciences and Technology, 2: 65-71.

Wikipedia. http://en.wikipedia.org/wiki/ tomato. Accessed December 11, 2011.

Yip, W. K. and S. F. Yang (1986). Effect of thidiazuron in cytokinin dependent ethylene production system. Plant Physiol., 80: 515519. 
تأثير كل من مركب Thidiazuron والمنفصل النباتي على كفاءة الإكثار المعملي الكثيف لنباتات الطماطم الشيري

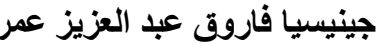 \\ قسم البساتين، كلية الزراعة، جامعة قناة السويس، الإسماعيلية
}

تعتبر الطماطم الثيري من أهم محاصيل الخضر التي تزرع بغرض التصدير في مصر. تم تقييم قدرة الطماطم الثنيري للإكثار

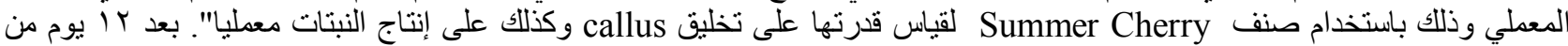

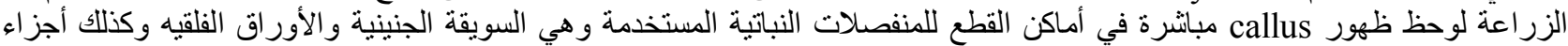

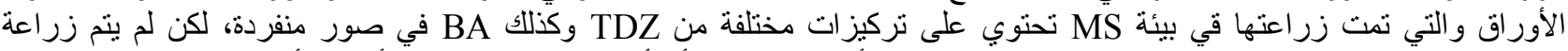

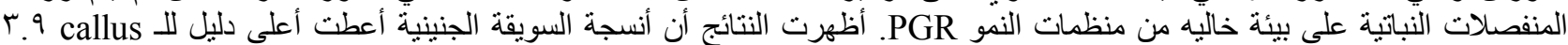

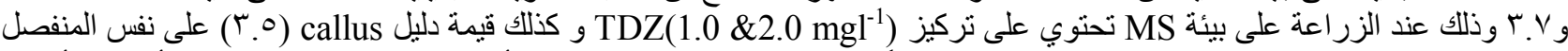

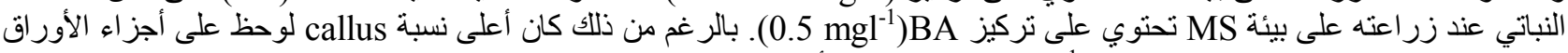

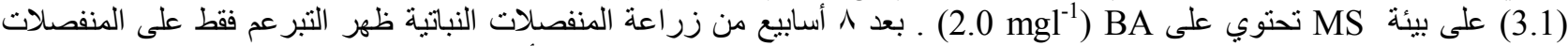

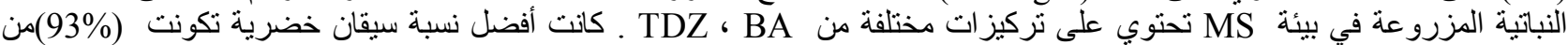

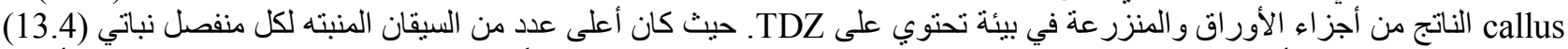

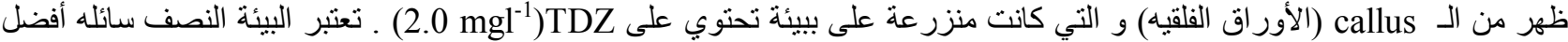

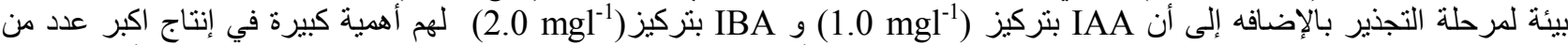

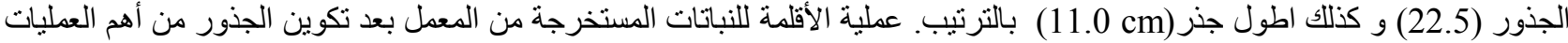

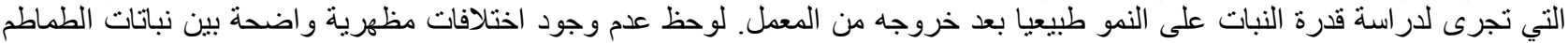

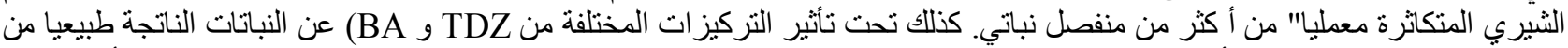

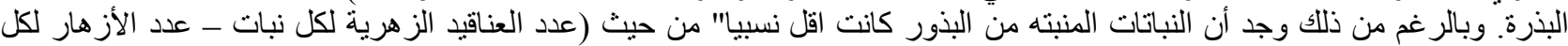

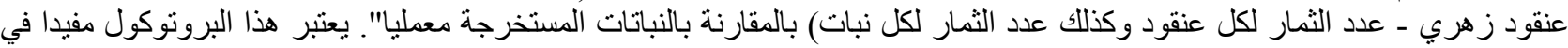
بر امج تحسين الصفات الور اثية وكذللك تطوير إنتاج الطماطع الثيري. 